\title{
The Analysis of a Rail Vehicle with a Tilting Bogie
}

Mária Maňurová, Andrej Suchánek

Faculty of Mechanical Engineering, University of Zilina, Univerzitná 8215/1, 01026 Žilina. Slovak Republic. E-mail: maria.manurova@fstroj.uniza.sk, andrej.suchanek@fstroj.uniza.sk

The paper deals with simulation analysis of a rail vehicle with a tilting bogie. The goal is to determine the wheel force in the rail-wheel contact and subsequently determine the safety against derailment. The rail vehicle model was designed in CAD program CATIA and imported to program SIMPACK with the RAIL module extension afterwards. Eight variants of different velocity, vehicle occupancy and setting of the tilting mechanism were analysed. The vehicle model was run along a track composed of straight sections and four succesive curves. Diagrams of the examined quantities icluding the lateral flanging force, vertical wheel load and the safety against derailment for the eight different variants make the result of the simulation analysis. Arising from the analysis, the biggest differences of results can be seen between the two variants of the highest speed but with different occupancy.

Keywords: Simpack, Rail-wheel contact forces, Safety against derailment, Simulation

\section{Acknowledgement}

This paper was created during the processing of the project "RAILBCOT - RAIL Vehicles Brake COmponents Test Stand", ITMS Code 26220220011 based on the support of Research and Development Operational Program financed by European Fund of a Regional Development. The work was also supported by the project No. APVV-0842-11: “Equivalent railway operation load simulator on the roller rig".

Research-Educational Center of Rail Vehicles (VVCKV)

\section{References}

[1] GERLICI, J. (2013). Comfort for passengers of rail vehicle assessment. In: Advanced methods in computational and experimental mechanics. London: Pearson Education Limited, 2013. (Pp. 141-172). ISBN 978-1-78434-0698.

[2] LACK, T., GERLICI, J. (2008). Analysis of vehicles dynamic properties from the point of view of passenger comfort. In: Communications: Scientific Letters of the University of Žilina. ISSN 1335-4205. Vol. 10, No. 3 (2008), (pp. 10-18).

[3] GERLICI, J., LACK, T., ONDROVÁ, Z. (2007). Evaluation of comfort for passengers of railway vehicles. In: Communications: Scientific Letters of the University of Žilina. ISSN 1335-4205. Vol. 9, No. 4 (2007), (pp. 44-49).

[4] LACK, T., GERLICI, J. (2007). Vehicles dynamical properties analysis from the point of view of comfort for passengers. In: Archives of Transport. ISSN 0866-9546. Vol. 19, No. 1-2 (2007), (pp. 91-110).

[5] LACK, T., GERLICI, J. (2015) Freight car bogie properties analysisby means of simulation computations. [Analýza vlastností železničného nákladného podvozka pomocou simulačných výpočtov.] In: PRORAIL 2015: zborník prednášok XXII. medzinárodnej konferencie Súčasné problémy v kol’ajových vozidlech. Žilina, 16.-18.9.2015, Slovak Republic. Žilina. 2015. - ISBN 978-80-89276-48-6. - S. 345-354. (In Slovak)

[6] GERLICI, J., LACK, T. (2009). Railway wheel profile development based on the geometric characteristics shapes. In: Contact mechanics and wear of rail/wheel systems = CM2009: 8th international conference: 15th-18th September 2009, Firenze, Italy. - Firenze: AB EDITORE, 2009. - ISBN 978-88-904370-0-7, (pp. 961-967).

[7] GERLICI, J., LACK, T. (2003). Rail geometry analysis (from the point of view of wearing in the operation). In: Communications - scientific letters of the University of Žilina. ISSN 1335-4205. - Vol. 5, No. 1 (2003), (pp. 4351).

[8] GERLICI, J., LACK, T. (2004). The Rail-Wheel contact. [Kontakt železničného dvojkolesia a kol'aje]. University of Žilina, ISBN 80-8070-317-5. (p. 200). (In Slovak)

[9] GERLICI, J., LACK, T., LACKOVÁ, M. (2004). Calculation of the equivalent conicity function of the railway wheelset tread profile at the Delta $\mathrm{R}$ function with a negative slope. In: Communications - scientific letters of the University of Žilina. ISSN 1335-4205. - Vol. 6, Nr. 2 (2004), (pp. 49-56).

[10] LACK, T., GERLICI, J. (2009). Railway wheel and rail roughness analysis. In: Communications: Scientific Letters of the University of Žilina. Vol. 11, No. 2 (2009), (pp. 41-48). ISSN 1335-4205. 
[11] LACK, T., GERLICI, J. (2013). Tangential stresses for non-elliptical contact patch computation by means of modified FASTIM method. In: IAVSD 2013: 23rd international symposium on dynamics of vehicles on roads and tracks: 19.-23. August 2013, Qingdao, China: proceedings. Chengdu: Southwest Jiaotong University, (p.6).

[12] LACK, T., GERLICI, J. (2013). The FASTSIM method modification in speed up the calculation of tangential contact stresses between wheel and rail. In: Manufacturing technology: journal for science, research and production. Vol. 13, no. 4 (2013), (pp. 486-492). ISSN 1213-2489.

[13] GERLICI, J., LACK, T. (2006). Synthesis of railway wheel and rail head profiles via the usage of arcs radii profile variation. In: Zeszyty naukowe Instytutu Pojazdów: mechanika, ekologia, bezpieczeństwo. 1 (60)/2006, (pp. 6178). ISSN 1642-347X.

[14] GERLICI, J., LACK, T. (2011). Railway wheel and rail head profiles develpment based on the geometric characteristics shapes [Vývoj profilov železničného kolesa a hlavy kol'ajnice na základe tvarov geometrických charakteristík] In: Wear : an international journal on the science and technology of friction, lubrication and wear. Vol. 271, No. 1-2 Sp. iss. (2011), Pp. 246-258. ISSN 0043-1648

[15] GERLICI, J., LACK, T. (2010). Contact geometry influence on the rail / wheel surface stress distribution. In: Procedia Engineering. ISSN 1877-7058. - Iss. 1 (2010), (pp. 2249-2257).

[16] LACK, T., GERLICI, J. (2008). Interational method for railway wheel tread profile design. In: XVIII konferencja naukova - pojazdy szynowe: Katowice-Ustroń, 17-19 września 2008: Materialy konferencyjne, (pp. 137-149).

[17] DIŽO, J., LACK, T., GERLICI, J. (2013). Využitie počítačovej simulácie pri hodnotení komfortu jazdy kol'ajových vozidiel. In: Železničná doprava a logistika. ISSN 1336-7943. Roč. 9, č. 1 (2013), Pp. 48-56. (In Slovak)

[18] DIŽO, J., GERLICI, J., LACK, T. (2013). The passenger car ride comfort assessment by means of ADAMS/Rail software utilization [Vyhodnotenie komfortu pre pasažierov osobného vagóna využitím programu ADAMS/Rail] In: TRANSCOM $2013: 10$-th European conference of young researchers and scientists. June 24-26, 2013, Slovak Republic. University of Žilina, 2013. Pp. 67-70. ISBN 978-80-554-0695-4.

[19] GERLICI, J., LACK, T. (2012). Wheelset rolling influence on the geometric characteristics shape. [Vplyv naklonenia dvojkolesia na tvar geometrických charakteristík] In: Dynamika tuhých a deformovatelných těles 2012. Univerzita J. E. Purkyně, 2012. - ISBN 978-80-7414-500-0. (In Slovak)

[20] DIŽO, J. (2015). Evaluation of ride comfort for passengers by means of computer simulation [Vyhodnotenie jazdného komfortu cestujúcich pomocou počítačovej simulácie] In: Manufacturing technology : journal for science, research and production. ISSN 1213-2489. Vol. 15, no. 1 (2015), s. 8-14. ISSN 1213-2489.

[21] DIŽO, J., BLATNICKÝ, M., SKOČILASOVÁ, B. (2015). Computational modelling of the rail vehicle multibody system including flexible bodies [Počítačové modelovanie viactelesového systému kol'ajového vozidla obsahujúceho pružné telesá] In: Communications : scientific letters of the University of Žilina. Vol. 17, no. 3 (2015), s. 3136. ISSN 1335-4205.

[22] ŠŤASTNIAK, P., HARUŠINEC, J. (2013) Computer aided simulation analysis for computation of modal analysis of the freight wagon. In: Communications : scientific letters of the University of Žilina. ISSN 1335-4205. Vol. 15, no. 4 (2013), s. 73-79. ISSN 1335-4205.

[23] ŠŤASTNIAK, P. (2015) Freight Long Wagon Dynamic Analysis in S-Curve by Means of Computer Simulation. In: Manufacturing Technology. 2015, vol. 15, iss. 4, (pp. 930-935). ISSN 1213-2489.

[24] HARUŠINEC, J., ŠŤASTNIAK, P., DIŽO, J. (2013) Calculations and simulations in the rail vehicle constructions development. [Výpočty a simulácie pri vývoji konštrukcií kol’ajových vozidiel] In: Technológ : časopis pre teóriu a prax mechanických technológií. Vol. 5, č. 3 (2013), Pp. 239-244. ISSN 1337-8996.

[25] NANGOLO, F., SOUKUP, J. (2014). The Effect of Asymmetry on Vertical Dynamic Response of Railway Vehicles. In: Manufacturing Technology: Journal for science, research and production. Univerzita J. E. Purkyně in Ústí n. Labem. October 2014, Vol. 14, No. 3 Pp. 375-380. ISSN 1213-2489.

[26] SIMPACK A.G. (2014). Documentation to the program system SIMPACK.

[27] SKOČILAS, J., SKOČILASOVÁ, B., SOUKUP, J. Determination of the rheological properties of thin plate under transient vibration. Latin American Journal of Solids and Structures. Brasil society for mechanics and engineering. ISSN 1679-7817 (print), 1679-7825 (online).

[28]SVOBODA, M., SOUKUP, J. (2013). Dynamic measurement of four-axle railway wagon. In: Manufacturing Technology. 2013, vol. 13, iss. 4, (pp. 552-558). ISSN 1213-2489. 